\title{
Determination of Reading Levels of Primary School Students
}

\author{
Hülya Kodan \\ Faculty of Education, Bayburt University, Turkey
}

Copyright $(2017$ by authors, all rights reserved. Authors agree that this article remains permanently open access under the terms of the Creative Commons Attribution License 4.0 International License

\begin{abstract}
In this study, it was aimed to evaluate the reading performances of $2 \mathrm{nd}, 3 \mathrm{rd}$ and 4 th graders. The study was designed in a scanning model. The research was conducted with 2nd, 3rd and 4th grade students studying in Bayburt, Turkey. The appropriate reading rates, reading speeds and reading errors of the students were examined by asking them to read a narrative text appropriate to their class. The texts were selected from the books distributed to the schools by the Ministry of National Education. Error Analysis Inventory was used to diagnose reading difficulties of students and to collect data about their reading performances. It was used to determine the reading levels of the readers individually. The present study is important since it identify students with reading difficulties and determines the necessary programs to overcome these difficulties.
\end{abstract}

Keywords Reading Difficulties, Reading Errors, Reading Speed

\section{Introduction}

Reading is described as "the process of deriving meaning through a goal and strategy, based on effective communication between reader and the author, where the reader configures the new information with her current knowledge in a convenient environment. [1]. In literature it is possible to find plenty of definitions about both physical and mental dimensions of reading [2, 3, 4]. Considering these definitions, it is not accurate to limit reading only to word recognition or deprive meaning. It is an active process in which reading, analysis and comprehension are taken place together.

An important element of reading education is reading fluency. It refers to fast, accurate and expressive reading activity. Akyol [5] describes the concept of reading fluency as "reading [a text] as talking to someone by paying attention to the punctuation marks, accent and tonal, abstaining from recurrence and word repetition, without spelling and unnecessary postures and by paying attention to the semantic units." Fluency is the ability to read a text correctly, smoothly and quickly with full expression and good comprehension $[6,7,8]$. Fluency occurs when students can decode text automatically. Students with fluency problems read words with hesitation and often have difficulties in reading certain words. Fluency is important because it ameliorate exhausting and laborious reading activity [9]. Accuracy in word recognition refers to the ability to read the text without pronunciation errors; automatic refers to being able to read a text correctly and easily, it also refers to good reader skills that can control comprehension during reading cognitive process, and prosody refers to reading a text with appropriate expression by reflecting its semantic and syntactic contents and to skills of interpreting it. Fluent reading should be as a natural conversation [10].

Fluent reading is an essential factor for reading comprehension to take place. If a text is read with difficulties and in impassive manner, students experience difficulties when deprive meaning from the text, that is, they establish connections between information in the text and their previous knowledge. The students will also have difficulties in understanding what they read. There are plenty of studies that set forth that students' comprehension skills are adversely affected when they have difficulties in reading fluency $[11,12,13,14,15,16,17]$.

Reading comprehension can be resembled to an umbrella from a broader perspective that includes word recognition, meaning of a word, and its phonetic and structural analysis. When the word recognition skills are not developed, problems arise in comprehension also [19].

Successful reading is a complex interaction of language, sensual perception, memory and motivation. In reading fluency, (1) word recognition and analysis (2) comprehension or structuring of textual understanding are the two important factors. During reading, the reader does not focus her attention on the two processes at the same time because she wants to proceed quickly. However, construction of meaning requires commenting, critical responses, etc. and generally requires attention. The non-fluent reader concentrates her attention to two processes sequentially; and for this reason, she experiences a though 
reading which often becomes agitated. Therefore, automatic analysis, an important element of fluency, is significant for reader to achieve high level of success in reading [20]. The development of reading is a process consisting of different stages. Development at each stage depends on learning concepts of the previous stages. Each stage is also a prerequisite for learning. Sub-areas of the reading-learning in the 2005 elementary Turkish instruction program were determined as voice awareness, discovering alphabetical relations (voice-to-letter matching), word recognition, fluent reading and reading comprehension. Reading instruction involves addressing these subfields respectively. In other words, student must have successfully accomplished the sub-areas of reading specified in the program in order to be able to gain reading skills.

Children who cannot read fluently experience concentration problems while reading. They additionally make reading errors such as reverse transitions, skipping (dropping and adding), and repetitions [21]. The mistakes made during the reading prevent students from understanding texts. For this reason, correct recognition of the word is required. Clear, systematic and intensive teaching is crucial for students who cannot read fluently to gain fluent reading and reading comprehension skills.

In order to apply necessary intervention programs for students who do not have fluent reading skills, it is necessary to determine students' reading and comprehension levels. In this case, teachers have important responsibilities.

Analyzing the reading levels will provide important information to us for identifying the factors that affect student's ability to learn reading skills. A comprehensive evaluation about reading performance is so significant; to determine the weaknesses and limitations of students by identifying difficulties of students during reading and to find out the sources of the problem and to assist the parents and teachers in preparing the intervention program (individualized education practices) according to students' needs. Good assessment also plays an important role in providing information about the students' development status [22]. Especially class teachers have a very important role in the first teaching reading and writing phase in the school education. For children to be more successful in their future lives, it is important to assess their reading performance in a vigorous way and to prepare the intervention program accordingly.

In recent years, close monitoring of student performances at different disciplines and class levels across the world, both nationally and internationally, is considered to be significant in assessment of national education policies and programs. Such assessments are crucial in increasing the quality of education and in determining overall trends in success. There is a range of reading assessments that lead to more decisive teaching practices beyond large-scale overall assessments of children's momentary success. However, these tests, which are not used in Turkey, are standardized or informal that can be applied to individuals or groups. These assessments give teachers the opportunity to examine students in depth as readers. The level of achievement of students gives information about their reading difficulties and interests at some extent [23].In Turkey, reading is the most emphasized language skill in the 2005 Turkish Instruction Curriculum. However, many students, considering their class level, are having problems with reading fluently. There are two reasons for this. First: students come to the class unprepared and usually fall behind their classmates. Over time, these students turn out to be poor readers. When the class acquires the general reading skills, teachers speed up to teach new subjects and these students are neglected. The second reason is that the reading processes of poor readers are not addressed in the following grades [24]. For providing an effective teaching it is important to determine and overcome the deficiencies of the students with reading difficulties. This study is also considered to be important in terms of determining reading levels of primary school students and assisting teachers and parents about preparing educational programs.

The main purpose of this research is to investigate reading levels of primary school students (2nd, 3rd and 4th graders). The aim of the research described here answer to the following questions.

1. What are the reading levels of 4 th, 3 rd and 2 nd grade primary schools students?

2. Is there a difference in students' reading levels according to gender?

3. Is there a meaningful difference between students' reading performances (number of errors, number of words per minute, words recognition percentages, and overall duration)?

4. What types of the errors do students make according to their grades?

5. Does the frequency of reading errors of the groups formed according to reading levels differ significantly from each other?

\section{Method}

\subsection{Model of the Research}

The research was designed in a scanning model [25], which aims to collect data to determine the specific characteristics of a group. Screening models are research approaches that aim to describe a fact as it was in the past or is in the present [26]. On the basis of this model, independent variables were determined as reading levels based on grades, gender and correct reading rates. And the dependent variables were frequency and reading performances (reading speed, word recognition percentage and reading errors) of the students who had reading problems in specified classrooms.

\subsection{Study Group}

The study group was consisted of 255 students, whose 
mother tongue is Turkish, from the $2^{\text {nd }}, 3^{\text {rd }}$ and $4^{\text {th }}$ grades in three primary schools in the central district of Bayburt. The socio-economic statues of the selected schools were at the medium level. Permission was obtained from the necessary institutions and study was carried out on the basis of volunteerism. Reading performance of students was evaluated individually. For each student a sufficient reading time was given.

\subsection{Data Collection Tools}

In order to collect data on oral reading performances reading texts and the "Error Analysis Inventory" was used. The Error Analysis Inventory used in the study was adapted to Turkish by Akyol [27], using Harris and Spay [28], Ekwall and Shanker [29] and May [30]. This inventory serves to determine the comprehension and individual reading level of readers. In this study, however, it is only aimed to determine the reading level. When the students made oral reading, their word recognition levels were determined, and at the same time, their vocal reading mistakes were identified with details. Three different reading levels are identified through this inventory [5]: Anxiety level (individual makes several reading errors and understands very little from her/his reading), Teaching Level (individual needs support from a teacher or an adult for reading and comprehension), Independent level (individual can read and comprehend the reading materials appropriate to her level without support from a teacher or an adult). In Anxiety Level, one makes a large number of reading mistakes and comprehends very little of what she reads. In Teaching Level, one needs the support of a teacher or an adult to comprehend what she reads and read in a preferred way. In Independent Level, one reads and comprehends the texts appropriate her level, without the need of a teacher or an adult person. Levels of oral reading skills of students: Independent level is $95-100 \%$, Teaching level is $90-94 \%$ and Anxiety level is $89 \%$ and below [31]. The texts used to determine reading levels of the students' were selected from Turkish textbooks distributed to elementary schools free of charge according to their grade level by the Ministry of National Education.

\subsection{Application of Data Collection Tool}

In order to determine their reading levels, the students were asked to read orally a Turkish narrative text from the textbooks approved by the Board of Education: "Little Lemon Tree" (consists of 399 words) from 4rd grade textbook for Turkish class, "Anatolia" (consists of 240 words) from 3rd grade textbook for Turkish class and "Little Rockfish" (consists of 177 words) from 3rd grade textbook for Turkish class [32-33-34]. The researcher reported the overall duration after when students were reading the texts. The researcher also marked the places where they misread and corrected themselves on the text and took notes about their reading performances. In addition, the students were recorded by a voice recorder when reading texts.

\subsection{Data Analysis}

During the application phase, each student read the selected reading text once, and the readings were recorded on the voice recorder. Errors that students made during reading and reading speeds were noted. In order to increase the reliability of the study, the students' readings were listened to again by the researcher and the reading records were decoded and scored according to the Error Analysis Inventory. The data obtained from the Error Analysis Inventory were analyzed with the Statistic Program for Social Sciences (SPSS, version 10.0). The data on the reading levels of the students were presented as frequency and percentage. And the Chi-square test was used to analyze if there is difference between their reading levels according to gender. And the Factor Analysis of Variance (Anavo) Test was analyzed to set forth the difference between students' reading level and reading performance (number of error words, reading speed, word recognition percentages, and reading durations).

Students' oral reading errors were examined in five groups; skipping, adding, repeating, misreading and reversing. The frequency of oral reading mistakes helps researcher to determine the students' level of reading. Moreover, as the frequency of oral reading mistakes increases, the reading level of the student will decrease, which will make reading comprehension insufficient.

The reading speed of the students was evaluated in terms of number of words per minute and reading duration of the whole text. It was predicted that reading speed of the students would be 80 words per minute at the $2^{\text {nd }}$ grader's level, 100 words per minute at the $3^{\text {rd }}$ grader's level and 120 words per minute at $4^{\text {th }}$ grader's level [35].

When the word recognition percentages of the students were calculated, the percentage of correct words read per minute was taken into consideration. This percentage is calculated by dividing the number of correct words into the total words (correct or incorrect read words) [23].

\section{Findings}

\subsection{Findings Related To the First Sub-Problem}

The findings related to the first sub-problem "what are the reading levels of 4 th, 3rd and 2nd grade primary schools students?" are presented below.

The data on the reading levels of the 4th, 3rd and 2nd grade primary school students are presented in Table 1.

Table 1 shows that reading levels of 105 students (41.18\%) out of 255 students were at the independent level, 75 students (29.41\%) were at the teaching level and 75 students (29.41\%) were at anxiety level. Based on these data and reading levels in terms of the $2^{\text {nd }}$ grades, 34 students out of $76(44,73 \%)$ were at the independent level, 21 students $(27,63 \%)$ were at 
the teaching level and 21 students $(\% 27,63)$ were at the anxiety level. Considering 3rd graders; 31 students (39.24\%) out of 79 students were at the independent level, 25 students (31.64\%) were at the teaching level and 23 students $(29.11 \%)$ were at the anxiety level. Considering 4 th grade students, 40 students $(40 \%)$ out of 100 students were at the independent level, 29 students (29\%) were teaching level and 31 students $(31 \%)$ were at the anxiety level.

Table 1. Reading Levels of Students

\begin{tabular}{|c|c|c|c|c|}
\hline \multirow[b]{2}{*}{ Grade } & \multicolumn{3}{|c|}{ Reading Levels } & \multirow[b]{2}{*}{ Tota } \\
\hline & $\begin{array}{l}\text { Independent } \\
\text { Level } \\
(\% 95-100)\end{array}$ & $\begin{array}{l}\text { Teaching } \\
\text { Level } \\
(\% 94-90)\end{array}$ & $\begin{array}{l}\text { Anxiety } \\
\text { Level } \\
\text { (\%89 or } \\
\text { below) }\end{array}$ & \\
\hline 2 & 34 & 21 & 21 & 76 \\
\hline 3 & 31 & 25 & 23 & 79 \\
\hline 4 & 40 & 29 & 31 & 100 \\
\hline Total & 105 & 75 & 75 & 255 \\
\hline
\end{tabular}

\subsection{Findings Related To the Second Sub-Problem}

The findings related to the second sub-problem "is there a difference in students' reading levels according to gender?" are presented below.

The results of the chi-square test about difference in reading levels of primary school students according to gender are shown in Table 2.

Table 2 shows that 50 students out the 127 female students were at the independent level, 40 students were at the teaching level, 37 students were at the anxiety level and 55 students out of the 128 male students were at the independent level, 35 students were at the teaching level, and 38 students were at the anxiety level. It is found that there was no significant difference between the students' reading levels and gender, $\mathrm{x}^{2}(\mathrm{sd}=2, \mathrm{n}=255)=.58, \mathrm{p}>.05$.

Table 2. Reading levels of students according to gender

\begin{tabular}{|c|c|c|c|c|}
\hline \multirow{2}{*}{ Gender } & \multicolumn{3}{|c|}{ Reading Levels } & \multirow{2}{*}{ Total } \\
\cline { 2 - 4 } & $\begin{array}{c}\text { Independent } \\
\text { Level } \\
(\% 95-100)\end{array}$ & $\begin{array}{c}\text { Teaching } \\
\text { Level } \\
(\% 95-100)\end{array}$ & $\begin{array}{c}\text { Anxiety } \\
\text { Level } \\
(\% 95-100)\end{array}$ & \\
\hline Female & 50 & 40 & 37 & 127 \\
\hline Male & 55 & 35 & 38 & 128 \\
\hline Total & 105 & 75 & 75 & 255 \\
\hline
\end{tabular}

$\mathrm{x}^{2}=.58 \mathrm{sd}=2 \mathrm{p}=.74$

\subsection{Findings Related to the Third Sub-Problem}

The findings related to the third sub-problem "is there a meaningful difference between students' reading performance (number of errors, number of words per minute, words recognition percentages, and overall duration)?" are presented below.

The results of the ANOVA analysis that examines if there is a meaningful difference between students' reading performance (number of errors, number of words per minute, words recognition percentages, and overall duration) are presented in Table 3.

Table 3 determines that there is a significant difference in students' reading errors and their reading levels. It is seen that there is a significant difference in number of errors in favor of anxiety level, while number of per minute and word recognition percentage in favor of independent level, and overall duration of the reading in favor of the anxiety level.

Table 3. Differences between reading errors per groups

\begin{tabular}{|c|c|c|c|c|c|c|}
\hline Variance & Group & Average & ss & $\mathrm{f}$ & $\mathrm{p}$ & Significant Difference \\
\hline \multirow{3}{*}{ Number of mistakes in the text } & Independent & 8.75 & 5.16 & \multirow{3}{*}{113.38} & \multirow{3}{*}{.000} & \multirow{3}{*}{$\begin{aligned} \mathrm{A} & >\mathrm{I} \\
\mathrm{A} & >\mathrm{T} \\
\mathrm{T} & >\mathrm{I}\end{aligned}$} \\
\hline & Teaching & 22.16 & 8.22 & & & \\
\hline & Anxiety & 52.78 & 34.46 & & & \\
\hline \multirow{3}{*}{ Number of words per minute } & Independent & 82.60 & 20.78 & \multirow{3}{*}{22.59} & \multirow{3}{*}{.000} & \multirow{3}{*}{$\begin{array}{l}\mathrm{I}>\mathrm{T} \\
\mathrm{I}>\mathrm{A} \\
\mathrm{T}>\mathrm{A}\end{array}$} \\
\hline & Teaching & 73.66 & 20.99 & & & \\
\hline & Anxiety & 59.77 & 25.91 & & & \\
\hline \multirow{3}{*}{ Word recognition percentage } & Independent & 96.91 & 1.32 & \multirow{3}{*}{254.13} & \multirow{3}{*}{.000} & \multirow{3}{*}{$\begin{array}{l}\mathrm{I}>\mathrm{T} \\
\mathrm{I}>\mathrm{A} \\
\mathrm{T}>\mathrm{A}\end{array}$} \\
\hline & Teaching & 92.14 & 1.41 & & & \\
\hline & Anxiety & 82.11 & 7.77 & & & \\
\hline \multirow{3}{*}{ Overall duration the text is read (min.) } & Independent & 3.73 & 86.17 & \multirow{3}{*}{20.11} & \multirow{3}{*}{.000} & \multirow{3}{*}{$\begin{array}{l}\mathrm{A}>\mathrm{I} \\
\mathrm{A}>\mathrm{T}\end{array}$} \\
\hline & Teaching & 4.38 & 114.83 & & & \\
\hline & Anxiety & 6.42 & 277.42 & & & \\
\hline
\end{tabular}




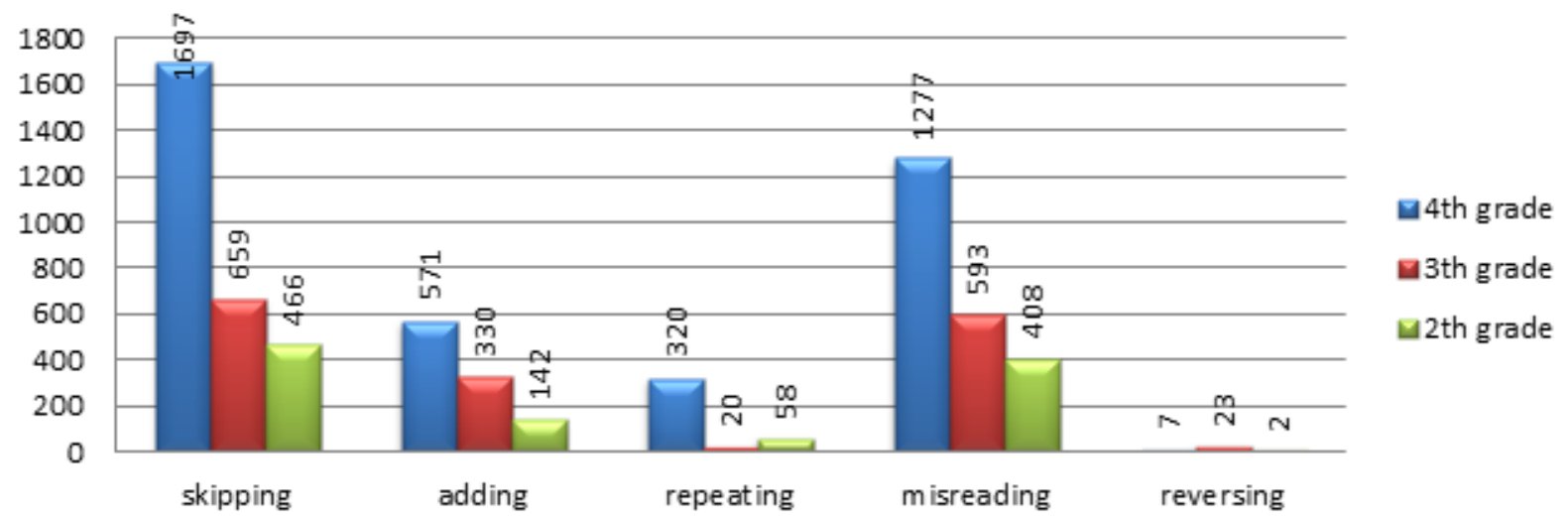

Graph 1. Types of error according to students' grades

Table 4. Frequency of reading errors of the groups formed according to reading levels

\begin{tabular}{|c|c|c|c|c|c|c|}
\hline Variance & Group & Average & SS & $\mathrm{f}$ & $\mathrm{p}$ & $\begin{array}{l}\text { Significant } \\
\text { Difference }\end{array}$ \\
\hline \multirow{3}{*}{ Skipping } & Independent & 3.82 & 3.30 & \multirow{3}{*}{74.44} & \multirow{3}{*}{.000} & \multirow{3}{*}{$\begin{array}{l}\mathrm{A}>\mathrm{I} \\
\mathrm{A}>\mathrm{T} \\
\mathrm{T}>\mathrm{I}\end{array}$} \\
\hline & Teaching & 9.65 & 6.01 & & & \\
\hline & Anxiety & 22.61 & 17.50 & & & \\
\hline \multirow{3}{*}{ Adding } & Independent & 1.84 & 1.93 & \multirow{3}{*}{41.19} & \multirow{3}{*}{.000} & \multirow{3}{*}{$\begin{array}{l}\mathrm{A}>\mathrm{I} \\
\mathrm{A}>\mathrm{T} \\
\mathrm{T}>\mathrm{I}\end{array}$} \\
\hline & Teaching & 4.20 & 2.71 & & & \\
\hline & Anxiety & 7.12 & 6.11 & & & \\
\hline \multirow{3}{*}{ Repeating } & Independent & 0.14 & 1.18 & \multirow{3}{*}{15.09} & \multirow{3}{*}{.000} & \multirow{3}{*}{$\begin{array}{l}\mathrm{A}>\mathrm{I} \\
\mathrm{A}>\mathrm{T}\end{array}$} \\
\hline & Teaching & 1.14 & 2.91 & & & \\
\hline & Anxiety & 3.96 & 7.79 & & & \\
\hline \multirow{3}{*}{ Misreading } & Independent & 3.17 & 2.39 & \multirow{3}{*}{74.20} & \multirow{3}{*}{.000} & \multirow{3}{*}{$\begin{aligned} \mathrm{A} & >\mathrm{I} \\
\mathrm{A} & >\mathrm{T} \\
\mathrm{T} & >\mathrm{I}\end{aligned}$} \\
\hline & Teaching & 7.08 & 3.77 & & & \\
\hline & Anxiety & 18.85 & 15.26 & & & \\
\hline \multirow{3}{*}{ Reversing } & Independent & 0.04 & 0.25 & \multirow{3}{*}{3.68} & \multirow{3}{*}{.027} & \multirow{3}{*}{$\mathrm{A}>\mathrm{I}$} \\
\hline & Teaching & 0.14 & 0.42 & & & \\
\hline & Anxiety & 0.21 & 0.55 & & & \\
\hline
\end{tabular}

\subsection{Findings Related To the Fourth Sub-Problem}

The findings related to the fourth sub-problem "what types of the errors do students make according to their grades?" is presented below.

The types of errors the students do according to their grades are presented in Graph1.

Graph 1 shows that the most frequent errors, that is, skipping, misreading, adding and repetition, were conducted by the 4 th graders. The reversal error is seen to be done more frequently by 3 rd graders.

\subsection{Findings Related To Fifth Sub-Problem}

The findings related to the fifth sub-problem "does the frequency of reading errors of the groups formed according to reading levels differ significantly from each other?" are presented below

The results of Anova statistics that shows if frequency of reading errors of the groups formed according to their reading levels differ significantly from each other are presented in Table 4.

Table 4 articulates that there is a significant difference in frequency of the errors made by students according to reading levels. It is also seen that there is a significant difference in frequency of skipping, adding, repeating, misreading and reversing in favor of the anxiety group.

\section{Conclusion, Discussion and Suggestions}

In the study it was aimed to reveal the reading levels of primary school students. Considering the reading levels of the students who participated to the study, it is seen that 34 students in 2nd grade, 31 students in 3rd grade and 40 students in 4th grade could read texts appropriate to their levels without support from a teacher or an adult. Similarly, 21 students in 2nd grade, 25 students in 3rd grade and 29 
students in 4th grade could read texts at a desired level with support from a teacher or an adult. In addition, 21 students in 2nd grade, 23 students in 3 rd grade and 31 students in $4^{\text {th }}$ grade were at the anxiety level and made several reading mistakes.

In general, in terms of the reading levels of 255 students; 105 students $(41.18 \%)$ were at the independent level, 75 students $(29.41 \%)$ were at the teaching level and 75 students (29.41\%) were at the anxiety level. There is no study in Turkey that shows proportion of students with reading difficulties. However, according to these results it is possible to conclude that $29.41 \%$ of 255 students cannot be ignored. Ergül [36], in his study about evaluating 112 students with reading difficulties in terms of reading performance, found that $13 \%$ of students were experiencing reading difficulties. Literature shows that about $10 \%$ of the school-age children in general are suffering from reading difficulties; nonetheless, some sources have higher rates [37]. Considering these findings, the results of the present research is very striking.

One of the results of the research is that there is no difference in reading levels of primary school students according to their gender. Nass [38] in his study on gender differences in learning stated that male students experience more learning difficulties compared to female students. Sandu et al. in their study named "gender differences in grey-white article structure of normal reading and dyslexic adolescents" determined that the rate of males experiencing reading difficulties is higher than females [39]. Flannery et al. [40], Rutter et al. [41] found that reading difficulty in males was seen more frequently than females. These studies show that the rate of reading difficulty according to gender is not a consequence. In their study named "dyslexia gender ratio and cognitive profiles" Jimenez et al concluded that the rate of reading difficulties of students did not differ according to the gender. The study also articulated that gender was not a decisive criterion for reading difficulties [42]. Bingöl [43] also found that there was no significant difference in reading difficulties according to gender in his research on primary and secondary school students in Ankara. The results of these studies support the conclusion of the present research.

It was also found that the errors made by the students were significantly different according to the reading levels. It is observed that the students in anxiety level made more errors than the students at the teaching and independent levels. Similarly, their number of words per minute and word recognition percentages was lower and duration of the reading of a text was longer compared to the students at the teaching and independent levels. The studies conducted on reading difficulties have parallel results with the present research regarding to the students with low reading levels $[44,45,46,36]$. Because students with reading difficulties do not have enough word recognition skills, they spend more time for word analysis. For this reason, students with reading difficulties read slower and make more mistakes compared to normal readers $[47,48]$. When students' reading speeds are evaluated according to the criteria specified by Güneş [35], it appears that students at anxiety level read more slowly than they supposed to read according to their class level. Students with sufficient reading skills are more likely to have better word recognition skills and reading speed than students with reading difficulties. This result of the present study has parallels with the research conducted by Gökçe Sarıpınar and Erden [49].

Considering the types of errors that students make from rarely to most frequently, it is seen that they make skipping, misreading, adding, repeating and reversing. These errors, except reversing, were mostly done by the 4 th graders. Yilmaz [50] in his research named "effects of word repeat technique on developing fluent reading skills" which was conducted with 5th, 6th, 7th and 8th grade students found that the most frequent mistake made by all of these graders was the skipping. Dündar and Akyol [51] determined that the types of mistakes made by student with reading difficulties were misreading, skipping, adding, and reversing, respectively. Gökçe Sarıpınar and Erden [49] identified mistakes as skipping (skipping letter, syllable, line, etc.), misreading, as well as making up the end of the word, and following by finger. In the study conducted with third graders, Yilmaz [50] also found that students made mistakes such as skipping, adding, reading, and reversing. The oral reading errors in these studies have parallels with the mistakes done by the students in the present research.

In line with these results, students who are at risk of having reading difficulties should be identified. And, with necessary educational programs and interventions students with reading difficulties should be supported to overcome reading problems and their academic failures rooted that problem should be recovered. For children, who are our futures, to be better educated, their reading performances should be determined nationwide and an action plan should be prepared accordingly.

\section{Acknowledgements}

This article is the developed version of the paper presented at the 15th International Primary Teacher Education Symposium (USOS 2016).

The author thanks the students who participated to the study as well as the administrative staff in three primary schools in the central district of Bayburt for supporting the research.

\section{REFERENCES}

[1] Akyol, H. (2015). Türkçe ilk okuma ve yazma öğretimi. Ankara: Pegem A akademi.

[2] Güneş, F. (2008). Hızlı okuma ve anlamı yapılandırma. Ankara: Nobel. 
[3] Sidekli, S. \& Yangın, S. (2005). Okuma güçlüğü olan öğrencilerin okuma becerilerinin geliştirilmesine yönelik bir uygulama. Kazım Karabekir Eğitim Fakültesi Dergisi, 11, 393-413.

[4] Brassel, D. \& Rasinski, T. (2008). Comprehension that works: Taking students beyond ordinary understanding to deep comprehension. Huntington Beach.

[5] Akyol, H. (2006). Türkçe ögrretim yöntemleri. Ankara: Kök Yayıncilik

[6] Tankersley, K. (2005). Literacy strategies for grades 4-12: Reinforcing the threads of reading. Alexandria, VA: Association for Supervision and Curriculum Development.

[7] National Institute of Child Health and Human Development (2000). Report of the National Reading Panel: Teaching Children to Read.

http://www.nichd.nih.gov/publications/pubs/nrp/Pages/findin gs.aspx. Accessed on 01.07.2013 from.

[8] Zutell, J. \& Rasinski, T. V. (1991). Training teachers to attend to their student's oral reading fluency. Theory into Practice, 30(3).

[9] Wexler, J. A. P. (2007). The relative effects of repeated reading, wide reading, and a typical instruction comparison group on the comprehension, fluency, and word reading of adolescents with reading disabilities. (Doctoral dissertation). The University of Texas.

[10] Young, C. \& Rasinski, T. (2009). Implementing readers theatre as an approach to classroom: Fluency instruction. The Reading Teacher, 63(1), 4-13.

[11] Akyol, M. (2014). Yapılandırılmış akıcı okuma yönteminin üçüncü sınıf ögrencilerinin akıcı okuma ile okuduğunu anlama becerilerine etkisi. (Master's Thesis). Niğde Üniversitesi, Eğitim Bilimleri Enstitüsü, Niğde.

[12] Kouider, M. \& Brian, T. H. (2006). How problems of reading fluency and comprehension are related to difficulties in syntactic awareness skills among fifth graders. Reading Research and Instruction, 46(1), 73-94.

[13] Crowe, L. K. (2003). Comparison of two reading feedback strategies in improving the oral and written language performance of children with language-learning disabilities. American Journal of Speech-Language Pathology, 12, 16-27.

[14] Pany, D. \& McCoy, K. M. (1988). Effects of corrective feedback on word accuracy and reading comprehension of readers with learning disabilities. Journal of Learning Disabilities, 21(9), 546-550.

[15] Yildirim, K. and Rasinski, T. (2014). Reading fluency beyond English: investigations into reading fluency in Turkish elementary students. International Electronic Journal of Elementary Education, 7(1), 97-106.

[16] Yildirim, K., Rasinski, T., Ateş, S., Fitzgerald, S., Zimmerman, B. \& Yildiz, M. (2014). The relationship between reading fluency and vocabulary in fifth grade Turkish students. Literacy Research and Instruction, 53, 72-89.

[17] Baştuğ, M. \& Akyol, H. (2012). Akıcı okuma becerilerinin okuduğunu anlamayı yordama düzeyi. Kuramsal Ĕ̆itim Bilim Dergisi, 5(4), 394-411.

[18] Yildiz, M. (2013). Okuma motivasyonu, akıcı okuma ve okuduğunu anlamanın beșinci sınıf öğrencilerinin akademik başarılarındaki rolü. Turkish Studies-International Periodical for the Languages, Literature and History of Turkish or Turkic, 8(4), 1461-1478.

[19] Durkin, D. (1978). What classroom observations reveal about reading comprehension instruction. Technical Report University of Illinois.

[20] Pikulski, J. J. \& Chard, D. J. (2005). Fluency: Bridge between decoding and reading comprehension. The Reading Teacher, 58(6), 510-519.

[21] Akyol, H. (2005). Türkçe ilk okumayazma öğretimi. Ankara: Pegem A akademi.

[22] IDA (2009). Testing and evaluation. https://dyslexiaida.org/testing-and-evaluation/ Accessed on 10/07/2017.

[23] Akyol, H., Yıldırım, K., Ateş, S. Çetinkaya, Ç. \& Rasinski T. (2014). Okumayı değerlendirme. Ankara: Pegem A akademi.

[24] Baştuğ, M. \& Demirgüneş, S. (2016). Türkçe öğretimi ders işleme süreci. Susar Kırmızı, F. (Ed.), İlk ve ortaokullarda Türkçe öğretimi. (s. 17-60). Ankara: Anı Yayıncılık.

[25] Büyüköztürk, Ş., Kılıç Ç., Ebru, Akgün, Ö. E., Karadeniz, Ş., \& Demirel, F. (2006). Bilimsel Araştırma yöntemleri. Ankara: Pegem Akademi.

[26] Karasar, N. (2008). Bilimsel araştırma yöntemi. Ankara: Nobel Yy.

[27] Akyol, H. (2008). Yeni programa uygun Türkçe öğretim yöntemleri. Ankara: Kök Yayıncılık

[28] Haris, A. J. \& Sipay, E.D. (1990). How to increase reading ability: a guide to developmental \& remedial methods. 9th Edition. Longman.

[29] Ekwall, E. E. \& Shanker, J. L. (1988). Diagnosis and remedation of the disabled reader. (Third Edition). Allyn and Bacon Inc.

[30] May, F. B. (1986). Reading as communication: an interactive approach. (Second Edition). Merill Publishing Company.

[31] Rasinski, T. V. (2003), "Theory and Practice", The Fluent Reader, Scholastic Professional Book. Printed in the U.S.A

[32] İlköğretim Türkçe 2 Ders ve Öğrenci Çalışma Kitabı (2014). Milli Eğitim Bakanlığı.

[33] İlköğretim Türkçe 3 Ders ve Öğrenci Çalışma Kitab1 (2014). Milli Eğitim Bakanlığı.

[34] İlköğretim Türkçe 4 Ders ve Öğrenci Çalışma Kitabı (2014). Milli Eğitim Bakanlığı.

[35] Güneş, F. (2013). Türkçe öğretimi yaklaşımlar ve modeller. Ankara: Pegem A Akademi Yayıncılık

[36] Ergül, C. (2012). Okumada güçlük yaşayan öğrencilerin okuma performanslarının öğrenme güçlüğü riski açısından değerlendirilmesi. Kuram ve Uygulamada Ĕgitim Bilimleri, 12 (3), 2033-2050

[37] Pavey, B. (2007). The dyslexia- friendly primary school: A practical guide for teachers. Paul, Chapman Publishing.

[38] Nass, R. D. (1993). Sex differences in learning abilities and 
disabilities. Annals of Dyslexia, 43, 61-77.

[39] Sandu, A.L., Specht, K., B., H., Lundervold, A., Hugdahl, K. (2008). Sex differences in grey-white matter structure in normal-reading and dyslexic adolescents. Neuroscience Letters, 438, 80-84.

[40] Flannery, K. A., Liederman, J., Daly, L. \& Schultz, J. (2000). Male prevalence for reading disability is found in a large sample of black and white children free from ascertainment bias. Journal Int Neuropsychol Soc., 6, 433-442.

[41] Rutter, M., Caspi, A., Horwood, J. L., Goodman, R., Maughan, B., Moffitt, T. E., Meltzer, H., Carroll, J. (2004). Sex differences in developmental reading disability. American Medical Association, 291(16). 2007-2012.

[42] Jimenez, Juan E., C., Claudia G., Siegel, L. S., O’shanahan, I., Garcia, E., Rodriguez, C. (2011). Gender ratio and cognitive profiles in dyslexia: a cross-national study. Read Writ, 24 , 729-747.

[43] Bingöl, Ayşe (2003). Ankara'daki ilkokul 2. ve 4. sınıf ögrencilerinde gelişimsel disleksi oranı. Ankara Üniversitesi Tıp Fakültesi Mecmuası, 56 (2), 67-82

[44] Sidekli, S. (2010). Eylem Araștırması: İlköğretim dördüncü sınıf öğrencilerinin okuma ve anlama güçlüklerinin giderilmesi. TÜBAR-XXVII, 563-580.
[45] Ulu, H. \& Akyol, H. (2016). The effects of repetitive reading and PQRS strategy in the development of reading skill. Eurasian Journal of Educational Research, 63, 225-242.

[46] Dinç, R. (2017). Action research about development of reading and writing skills of dyslexic student. Kuramsal Eğitim Bilim Dergisi, 10(2), 230-334.

[47] Balc1, E. \& Çayir, A. (2017). Çoklu duyusal öğrenmenin disleksi riski olan bir ilkokul 4. Sınıf öğrencisinin fonolojik farkındalık becerisine etkisi. Ana Dili Ĕ̈itimi Dergisi, 5(2), 201-216.

[48] Akyol, H. \& Kodan, H. (2016). Okuma güçlüğünün giderilmesine yönelik bir uygulama: akıcı okuma stratejilerinin kullanımı. OndokuzMayıs Üniversitesi Eğitim Fakültesi Dergisi, 35(2), 7-21.

[49] Gökçe S., Esin \& Erden, G. (2010). Okuma güçlüğünde akademik beceri ve duyusal-motor işlevleri değerlendirme testlerinin kullanılabilirliği. Türk Psikoloji Dergisi, 25(65), 56-66.

[50] Yılmaz, M. (2008). Kelime tekrar tekniğinin akıcı okuma becerilerini geliştirmeye etkisi. Türk Eğitim Bilimleri Dergisi, $6(2), 323-350$

[51] Dündar, H. \& Akyol, H. (2014). Okuma ve anlama Problemlerinin Tespiti ve Giderilmesine İlişkin Örnek Olay Çalışması. Eğitim ve Bilim Dergisi, 39(171), 361-377. 